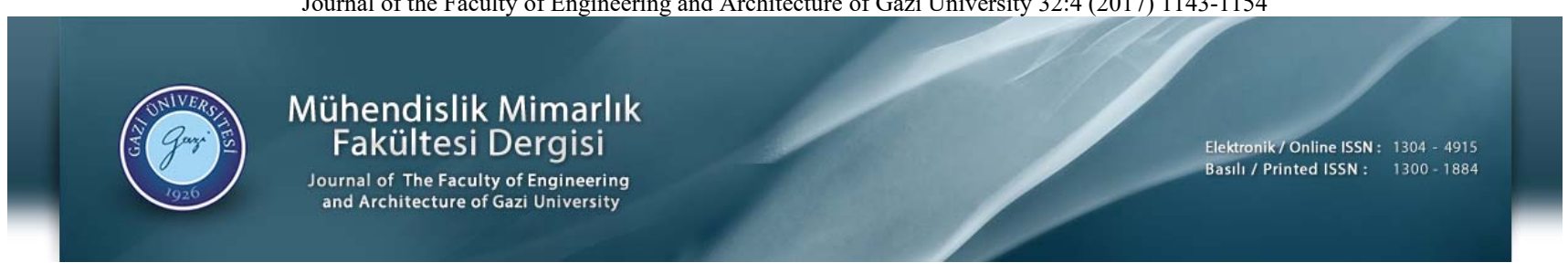

\title{
Çelik fiber katkı1ı etriyesiz betonarme kirişlerin davranışı
}

\author{
Selçuk Saatçi(iD*, Baturay Batarlar (D) \\ İzmir Yüksek Teknoloji Enstitüsü, İnşaat Mühendisliği Bölümü, 35430, Urla, İzmir, Türkiye
}

\section{Ö N E C I K A N L A R}

- Çelik fiber katkısının betonarme kiriş eğilme davranışına etkisi

- Çelik fiber katkılı betonarme kirişte çatlakta çekme gerilmelerinin modellenmesi

- Çelik fiber katkılı betonarme kiriş eğilme davranışının modellenmesi

Makale Bilgileri

Geliş: 15.07.2016

Kabul: 15.11 .2016

DOI:

$10.17341 /$ gazimmfd.369512

Anahtar Kelimeler:

Betonarme kirişler,

çelik fiber katk1lı beton,

betonarme kirişlerde kesme davranışı,

betonarme kirișlerde eğilme

davranışı,

çelik fiber katkısının

modellenmesi

\section{ÖZET}

Sunulan çalışmada çelik fiber katkısının farklı boyuna donatı oranlarına sahip etriyesiz betonarme kirişlerin eğilme davranışına olan etkileri deneysel ve analitik olarak incelenmiştir. Yapılan deneysel çalışmada düşük ve yüksek boyuna donatı oranına sahip iki grup kiriş imal edilmiştir. Her bir gruptaki kirişler hacimce $\% 0, \% 0,5, \% 1,0$ ve $\% 1,5$ çelik fiber oranına sahip olup toplam sekiz kiriş açıklık ortasına uygulanan yük altında test edilmiştir. Düşük boyuna donatı oranına sahip kirişlerde çelik fiber katkısı eğilme kapasitesini \%50'ye yakın oranlarda artırmış, ancak deformasyonların tek bir çatlakta toplanması sebebiyle boyuna donatıda kopmaya yol açarak çelik fiber katkısız kirişe göre daha az yerdeğiştirme yapmasına sebep olmuştur. Yüksek boyuna donatı oranına sahip kirişlerde ise çelik fiber katkısı etriye görevi görerek çelik fiber katkısı olmaması durumunda gevrek eğik çekme göçmesi gösteren kirişlerin sünek eğilme göçmesi göstermelerini sağlamıştır. Her iki grupta çelik fiber oranının arttırılması çatlak dağılımını etkilemekle birlikte davranışta önemli bir farklılığa yol açmamıştır. Kirişler analitik yöntemlerle modellendiğinde literatürde yaygın kullanılan ve çatlakta çelik fiberlerin taşıdığı çekme gerilmesini sabit kabul eden yaklaşımın güvenli tarafta olmakla birlikte eğilme kapasitesinin olduğundan düşük hesaplanmasına yol açtığı, çekme gerilmelerini çatlak genişliği ile ilişkilendiren daha hassas modellerin daha iyi sonuç verebilecekleri görülmüştür.

\section{Behavior of steel fiber reinforced concrete beams without stirrups}

\section{H I G H L I G H T S}

- $\quad$ Effects of steel fiber on the bending behavior of reinforced concrete beams

- Modeling crack tensile stresses in steel fiber reinforced concrete beams

- Modeling bending behavior of steel fiber reinforced concrete beams

Article Info

Received: 15.07.2016

Accepted: 15.11.2016

DOI:

10.17341/gazimmfd.369512

Keywords:

Reinforced concrete beams, steel fiber reinforced concrete, shear behavior in reinforced concrete beams,

bending behavior in reinforced concrete beams, modeling steel fiber contribution

\section{ABSTRACT}

In this study, effects of steel fibers on the bending behavior of reinforced concrete beams of varying longitudinal reinforcement ratios and without stirrups are investigated experimentally and analytically. In the experimental work, two groups of simply supported beams of low and high longitudinal reinforcement ratio were manufactured. Each group had $0 \%, 0.5 \%, 1.0 \%$ and $1.5 \%$ steel fiber ratio in volume. Eight beams were tested under a load applied at midspan. In the group with lower longitudinal reinforcement ratio, steel fibers increased the bending capacity by almost $50 \%$. However, since deformations were concentrated on a single crack, longitudinal reinforcement has ruptured and the beams could not displace as much compared to the one without steel fibers. In the group with higher longitudinal reinforcement ratio, steel fibers acted like stirrups and changed the brittle shear failure mode to a ductile bending failure. Although increasing the steel fiber ratio affected crack distributions, it did not cause a significant difference in the behavior. When analytically modeled using a common model that assume constant tensile stress at crack, computed bending capacities were lower than actual, although on the safe side. More precise models that relate tensile stresses to the crack width could give better estimations.

\footnotetext{
*Sorumlu Yazar/Corresponding Author: selcuksaatci@iyte.edu.tr / Tel: +90 2327506814
} 


\section{GİRIŞ (INTRODUCTION)}

Betonun çekme dayanımına olan katkısı sebebiyle özellikle çatlamanın istenmediği endüstriyel yapı zeminleri, silolar, sıvı tankları, iklim ve dış etkiler bakımından agresif ortamlarda inşa edilen yapılar gibi yapılarda çelik veya polipropilen lifler yaygın olarak kullanılmaktadır [1]. Çelik fiber genel olarak betonun malzeme ve yüzey özelliklerini iyileştirmek amacıyla kullanılmakta olup yük taşıyıcı elemanlarda betonun çekme dayanımını arttırmak amacıyla donatı takviyesi olarak kullanımı ise ancak son zamanlarda artan çalışmalarla mümkün olabilmiştir [2]. Çelik fiberlerin betonun çekme dayanımına olan katkılarından dolayı kayma dayanımını önemli ölçüde arttırdıkları görülmüş ve elde edilen bulgular doğrultusunda yap1 yönetmeliklerinde kayma donatısı olarak kullanımına yer verilmeye başlanılmıştır. Örneğin Amerikan Beton Enstitüsü'nün (ACI) yayınladığı ACI 318 yapı yönetmeliğinde belirli bir oranda çelik fiber kullanılan ve kayma gerilmesinin belirlenen limitlerin altında olduğu kirişlerde etriye kullanılmamasına izin verilmiş, başka bir deyişle çelik fiberlerin kullanılması zorunlu olan minimum etriye oranını karşıladığı kabul edilmiştir [3]. Ancak çelik fiber katkısının yapısal etkileri üzerine yapılan çalışmalar halen yetersiz düzeyde olduğundan güncel yönetmelikler çelik fiber katkısının eğilme kapasite ve davranışına olan katkılarının göz önüne alınmasına izin vermemektedirler.

Literatürde çelik fiber katkısının betonarme yap1 elemanlarının davranışı üzerine olan etkilerini inceleyen çok sayıda araştırma mevcuttur [4]. Betonarme kirişler üzerine son zamanlarda yapılan çalışmalar ağırlıklı olarak çelik fiber katkısının kesme davranışına olan etkileri üzerine odaklanmıştır [5]. Kirişlerin eğilme davranışı üzerine olan etkileri hakkında kapsamlı çalışmaların sayısı daha sınırlıdır [6]. Eğilme davranışı üzerine olan deneysel çalışmalar genelde basınç donatısı olmayan kirişler üzerinde dört noktalı eğilme yükü altında yapılmakta olup araştırılan ana konular çelik fiberin türü, boyu, oranı gibi parametrelerin davranışa olan etkileri olduğu için deney numunelerinde boyuna donatı oranı sabit tutulmaktadır [7]. Çelik fiber katkısının betonarme kirişlerin eğilme davranışına olan etkilerinin daha iyi anlaşılması için uygulamada çok yaygın olan basınç donatısı varlığının göz önüne alınması ve farklı boyuna donatı oranlarının davranış üzerine olan etkisinin araştırılması gerekmektedir. $\mathrm{Bu}$ amaçla burada sunulan çalışmada çelik fiber katkılı basınç donatılı betonarme kirişlerin eğilme davranışının anlaşılması yönünde bir deneysel çalışmaya yer verilmiş, yapılan çalışmada değişen boyuna donatı oranının davranışa olan etkileri de incelenmiştir. Yürütülen deneysel programda deney numuneleri boyuna donatı oranlarına göre iki gruba ayrılmıştır. Birinci grup (K1 serisi) sahip olduğu düşük boyuna donatı oranından dolayı eğilme kapasitesi kesme kapasitesinden düşük olduğundan eğilme göçmesi gösterirken ikinci grup (K2 serisi) daha yüksek boyuna donatı oranıyla kesme kapasitesinden daha yüksek eğilme kapasitesine sahiptir ve çelik fiber katkısı olmaması durumunda eğik çekme göçmesi göstermektedir. Her iki grubun da boyuna donatı oranı denge altıdır. Her iki grupta da etriye kullanılmamış, bu şekilde çelik fiberlerin eğilme davranışına olan etkilerinin etriye oranından bağımsız olarak incelenmesi hedeflenmiştir. Tüm numunelerde basınç donatısı oranı çekme donatısı oranına eşit tutulup kirişlerin yüksek derecede süneklik göstererek yüksek çatlak genişliklerine ulaşması sağlanmış, bu şekilde çelik fiberlerin geniş bir çatlak genişliği aralığında etkilerinin incelenmesi mümkün olmuştur. Her iki deney grubunda da dört farklı çelik fiber katkısı oranı ile üretilen numuneler test edilerek çelik fiber katkı oranının davranışa olan etkileri incelenmiştir. Ayrıca elde edilen sonuçların literatürde yaygın olarak kullanılan mevcut modellere göre analizleri yapilarak bu modellerin hassasiyet dereceleri de irdelenmiştir.

\section{DENEY PROGRAMI (EXPERIMENTAL PROGRAM)}

Çelik fiber katkılı betonarme kirişlerin davranışının incelenmesi amaciyla toplam sekiz adet kiriş numunesi test edilmiştir. Tüm deney numuneleri 150x250x2300 mm boyutlarındadır. Numuneler altta ve üstte simetrik olacak şekilde ikişer boyuna donatıya sahip olup paspayı $25 \mathrm{~mm}$ olarak bırakılmıştır (Şekil 1). Mesnetlerin merkezinden merkezine açıklık $2000 \mathrm{~mm}$ 'dir. Numunelerin tasarımında herhangi bir ölçek gözetilmemiştir. Numunelerin dördünde 8 mm çaplı (K1 serisi), dördünde ise $16 \mathrm{~mm}$ çaplı donatılar kullanılmıştır (K2 serisi). Boyuna donatılar uçlarında yaklaşık $150 \mathrm{~mm}$ kanca boyu birakacak şekilde $90^{\circ}$ bükülmüş, bu şekilde hem alt ve üst donatılar birbirlerine kancalarından bağlanarak üst donatıların etriyesiz yerleştirilmesi sağlanmış hem de boyuna donatıların ankrajı temin edilmiştir. Hiçbir numunede etriye kullanılmamıştır. Numune isimleri, kullanılan boyuna donatı ve çelik fiber katkısı oranları Tablo 1'de verilmektedir.

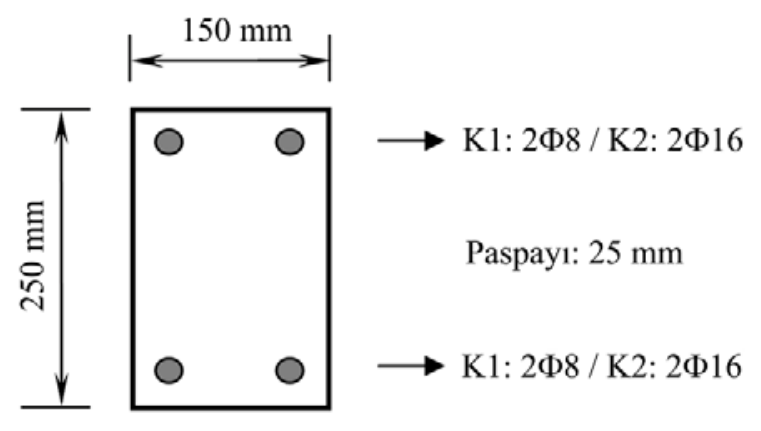

Şekil 1. Kiriş numuneleri kesiti (Beam specimen cross section)

Çelik fiberler arzu edilen hacimsel orana göre metreküp başına düşen çelik fiber ağırlığı hesaplanıp tartılarak beton karışımına eklenmiş, karışım üreticinin tavsiyeleri doğrultusunda beton mikserinde karıştırılmıştır. Hazırlanan karışımlardan 150x300 mm'lik standart silindir numuneler alınarak basma ve çekme dayanımları bulunmuştur. Tablo 2'de 28 günlük basma dayanımları ile yaklaşık olarak deneylerin yapıldığ 1 günlerde (dökümden yaklaşık 12 ay 
Tablo 1. Numune donatıları ve çelik fiber katkısı oranları (Specimen reinforcement and steel fiber ratios)

\begin{tabular}{llll}
\hline Numune & $\begin{array}{l}\text { Boyuna Donat } \\
\text { (altta }+ \text { üstte) }\end{array}$ & Çekme Donatıs1 Oran1 & $\begin{array}{l}\text { Celik Fiber Oran1 } \\
(\%, \text { hacimsel) }\end{array}$ \\
\hline $\mathrm{K} 1 \mathrm{~s} 0$ & $2 \Phi 8+2 \Phi 8$ & 0,003 & 0 \\
$\mathrm{~K} 1 \mathrm{~s} 05$ & $2 \Phi 8+2 \Phi 8$ & 0,003 & 0,5 \\
$\mathrm{~K} 1 \mathrm{~s} 10$ & $2 \Phi 8+2 \Phi 8$ & 0,003 & 1,0 \\
$\mathrm{~K} 1 \mathrm{~s} 15$ & $2 \Phi 8+2 \Phi 8$ & 0,003 & 1,5 \\
$\mathrm{~K} 2 \mathrm{~s} 0$ & $2 \Phi 16+2 \Phi 16$ & 0,012 & 0 \\
$\mathrm{~K} 2 \mathrm{~s} 05$ & $2 \Phi 16+2 \Phi 16$ & 0,012 & 0,5 \\
$\mathrm{~K} 2 \mathrm{~s} 10$ & $2 \Phi 16+2 \Phi 16$ & 0,012 & 1,0 \\
$\mathrm{~K} 2 \mathrm{~s} 15$ & $2 \Phi 16+2 \Phi 16$ & 0,012 & 1,5 \\
\hline
\end{tabular}

Tablo 2. Beton mekanik özellikleri (Concrete mechanical properties)

\begin{tabular}{lllc}
\hline & \multicolumn{2}{l}{ Basıç Dayanımı $(\mathrm{MPa})$} & $\begin{array}{l}\text { Yarmada Çekme Dayanımı (MPa) } \\
\text { Fiber oran1, \% }\end{array}$ \\
\hline 0 & 28 gün & Deney günleri (dökümden yaklaş1k 12 ay sonrası) \\
0,5 & 33,8 & 42,4 & 2,3 \\
1,0 & 36,7 & 49,3 & 3,5 \\
1,5 & 35,2 & 45,4 & 5,1 \\
\hline
\end{tabular}

sonrası) bulunan basma ve yarmada çekme dayanımları verilmektedir. Kullanılan çelik fiber $0,75 \mathrm{~mm}$ çapında 60 mm uzunluğunda iki ucu kancalı olup Dramix ${ }^{\circledR}$ RC-80/60BN ticari markasına sahiptir. Boyuna donatı S420 çeliği olup yapılan çekme deneyleri sonucu akma dayanımı $480 \mathrm{MPa}$, çekme dayanımı $590 \mathrm{MPa}$, akma birim uzaması 0,0025, pekleşmenin başladığı birim uzaması 0,024, kopma birim uzaması 0,12 olarak bulunmuştur.

Deney düzeneği Şekil 2'de verilmiştir. Yükleme bir hidrolik kriko vasıtasıyla aşağıdan yukarı yönlü uygulanmış olup mesnetler dönmeleri ve bir uçta yanal ötelenmeyi serbest bırakacak şekilde düzenlenmiş, bu şekilde basit mesnet koşulu elde edilmiştir. Yükleme yüzeyi $200 \mathrm{~mm}$ çapında dairesel çelik bir plakadan oluşmaktadır. Deneylerde uygulanan yük ve mesnetlerde ölçülen tepki kuvvetleri yük hücreleri ile, yerdeğiștirmeler ise kiriș altına ve biri tam açıklık ortasına olmak üzere üzerine belli aralıklarla yerleştirilen 13 adet RLPT (Resistive Linear Position Transducer) ile ölçülüp kaydedilmiştir.

\section{SONUÇLAR VE TARTIŞMALAR} (RESULTS AND DISCUSSIONS)

Deney sonuçlarının sağlıklı değerlendirilebilmesi için çelik fiber katkısı olmayan kirişlerin beklenen davranışlarının incelenmesi yerinde olacaktır. Tüm kirişler etriyesiz olup kesme açıklığının (a: mesnet ve yük arasındaki mesafe) faydalı yüksekliğe (d) oranı K1 serisi için 1000/221=4,52, $\mathrm{K} 2$ serisi için $1000 / 217=4,60$ 'tır. $\mathrm{Bu}$ a/d oranlarına sahip kesme donatısı ve çelik fiber katkısı bulunmayan kirişlerde boyuna donatının sağladığı eğilme kapasitesine göre eğik çekme göçmesi veya eğilme göçmesi beklenir. Kirişlerin eğik çatlama dayanımları hesabında TS 500'de [8] verilen formül (TS 500 Denklem 8.1) açıkça belirtilmeyen güvenlik katsayıları içerdiğinden etriyesiz kirişlerin eğik çatlama dayanımı hesabı için yaygın kabul gören ve ACI 318M-11'de de yer alan $V_{c r}=0.17 \sqrt{f^{\prime}} b_{w} d$ formülü kullanılmış [3] ve buna göre hesaplanan kesme dayanımları $\mathrm{K} 1 \mathrm{~s} 0$ için $36,7 \mathrm{kN}$, $\mathrm{K} 2 \mathrm{~s} 0$ için $36,0 \mathrm{kN}$ bulunmuştur. $\mathrm{Bu}$ kesme kuvvetleri sırasıyla $73,4 \mathrm{kN}$ ve $72,0 \mathrm{kN}$ uygulanan yüke karş1lık gelmektedirler. Kirişlerin eğilme kapasiteleri ise TS 500'e göre $\mathrm{K} 1 \mathrm{~s} 0$ için $11,0 \mathrm{kN} . \mathrm{m}, \mathrm{K} 2 \mathrm{~s} 0$ için $40,7 \mathrm{kN}$.m olarak hesaplanmış, kirişleri açıklık ortasında bu moment kapasitelerine ulaştıracak yükler, yükün 0,2 m'lik yükleme plakası boyunca düzgün yayılı olarak uygulandığı varsayımıyla, sirasiyla $23,2 \mathrm{kN}$ ve $85,7 \mathrm{kN}$ olarak bulunmuştur. Eğilme kapasitesi hesabında donatı pekleşmesi ihmal edilmiş, her iki kirişte de hesaplara göre boyuna çekme donatısının betonun ezilmesinden önce aktığı, dolayısıyla boyuna donatı oranının denge altı olduğu tespit edilmiştir. Maksimum eğilme ve kesme kapasiteleri dikkate alındığında eğilme kapasitesi kesme kapasitesinden çok daha düşük olduğu için $\mathrm{K} 1 \mathrm{~s} 0$ kirişinin eğilme göçmesi, K2s0 kirişinin ise kesme kapasitesi eğilme kapasitesinden düşük olduğu için eğik çekme göçmesi göstermesi beklenir.

Kirişlerin statik deneylerinden elde edilen yük-yerdeğiştirme eğrileri Şekil 3'te verilmektedir. Deneylerde ölçülen maksimum yük ve yerdeğiştirme değerleri Tablo 3 'te özetlenmekte, tüm kirişlerin göçme sonrası fotoğrafları ise Şekil 4 ve 5 'te sunulmaktadır. Düşük boyuna donatı oranına sahip K1 serisi kirişlerin tamamı beklenildiği gibi eğilme göçmesi göstermişlerdir. Çelik fiber katkısı olmayan K1s0 numunesinde 26,2 $\mathrm{kN}$ yükte çekme donatıs1 akması görülmüştür. Deneyde gözlemlenen akma yükü TS 500 kullanılarak hesaplanan yükten yaklaşık \%12 daha yüksektir. $\mathrm{Bu}$ kirişlerde çelik fiber katkısı kirişlerin yük kapasitesini 


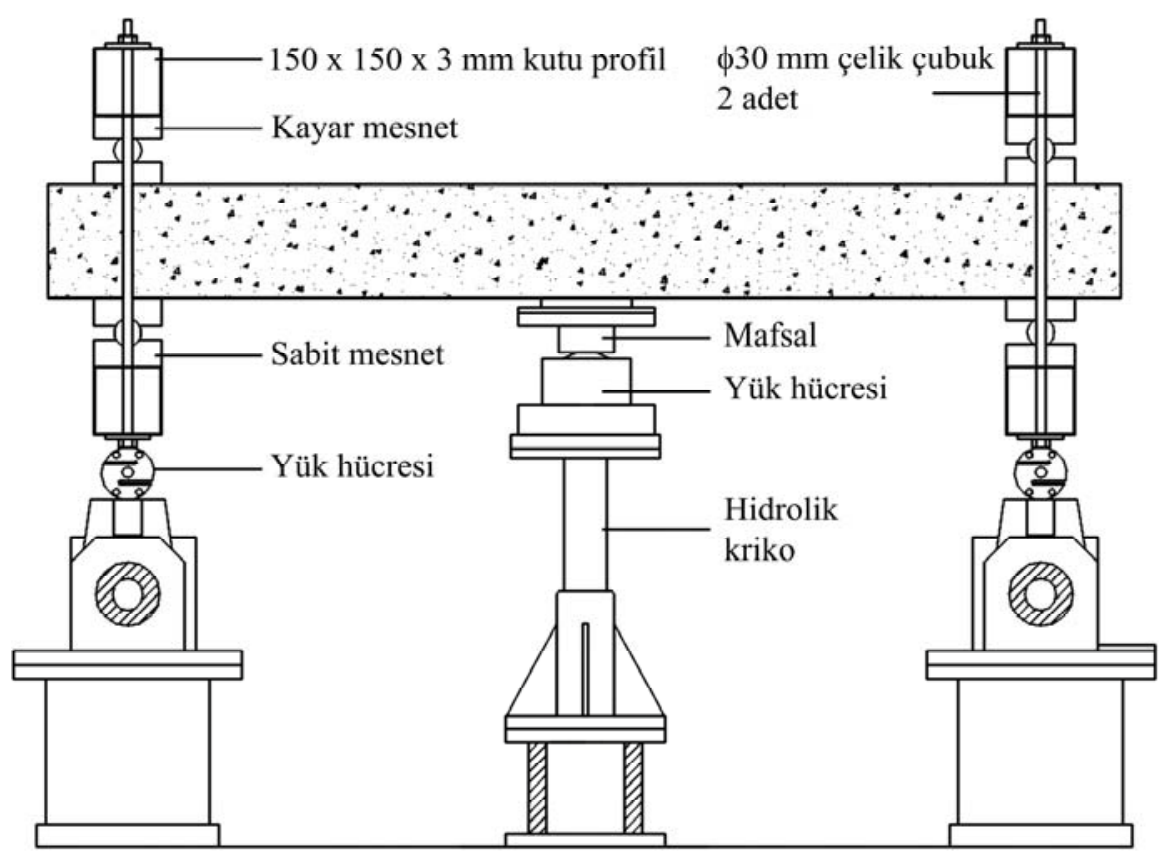

Yerdeğiştirmeleri ölçen RLPT'ler gösterilmemiştir.

Şekil 2. Deney düzeneği (Test setup)

önemli oranda arttırmıştır. Çelik fiber katkısı olmayan K1s0 numunesi $28,7 \mathrm{kN}$ yükte göçerken çelik fiber katkılı kirişler yaklaşık $42 \mathrm{kN}$ yükte çekme donatısının kopmasıyla göçmeye uğramışlardır. Çelik fiber katkısı yük kapasitesini yaklaşık \%45 arttırmıştır. Ancak çelik fiber katkı oranının arttırılmasının bu kapasite artışına önemli bir etkisi gözlemlenememiş, $\% 0,5, \% 1$ ve $\% 1,5$ çelik fiber katk1lı kirişlerin davranışları ve yük kapasiteleri büyük oranda aynı olmuştur.

Çelik fiber oranının artmasının çatlak dağılımını etkilediği gözlemlenmiştir. K1s05 numunesinde ortadaki ana çatlak göçme anında yaklaşık $4 \mathrm{~mm}$ genişliğinde iken bu çatlağın her iki yanında genişlikleri $0,1 \mathrm{~mm}$ ile $0,9 \mathrm{~mm}$ arasında değişen altı büyük çatlak daha oluşmuştur. K1s10 numunesinde ise ortadaki ana çatlak $6 \mathrm{~mm}$ genişliğe ulaşırken bu çatlağın dişında orta bölgede 1,2 mm genişliğinde bir tane büyük çatlak oluşmuştur. En yüksek çelik fiber oranına sahip K1s15 numunesinde ise ana çatlak $10 \mathrm{~mm}$ 'ye kadar açılmışken yanında $0,9 \mathrm{~mm}$ ve $0,7 \mathrm{~mm}$ genişliğinde iki çatlak daha oluşmuştur. Genel olarak çatlak dağılımları incelendiğinde artan çelik fiber oranının çatlak gelişimini az sayıda çatlakta topladığı, diğer çatlakların genişlemesini engellediği görülmektedir. Çelik fiber katkılı kirişler arasındaki en belirgin davranış farkı \%1,5 oranında çelik fiber katkılı kirişin diğer çelik fiber katkılı kirişlere oranla daha yüksek yerdeğiştirme değerlerine ulaşmasıdır. $\% 0,5$ ve $\% 1$ çelik fiber katkılı kirişler yaklaşık $41 \mathrm{~mm}$ yerdeğiştirmede göçmeye uğrarken \%1,5 çelik fiber katkılı kiriş $56 \mathrm{~mm}$ yerdeğiştirmede göçmüştür. Yaklaşı \%36 oranında fazla yerdeğiştirme yapan bu kirişin yüksek fiber oranından kaynaklanan çatlağı kesen çelik fiberlerin sayıca çok daha fazla olmasından dolayı ortadaki ana çatlağın 10 mm açılmasına kadar yük taşıyabilmesi kirişin daha fazla yerdeğiştirme yapmasına sebep olarak gösterilebilir. Daha düşük fiber oranına sahip kirişler bu çatlak genişliklerine ulaşmadan sıyrılarak yük taşıma kapasitelerini yitirmişlerdir. Çelik fiber katkısı olmayan K1s0 numunesi ise çelik fiber katkısı olan kirişlere oranla çok daha düşük yük kapasitesine sahip olmakla beraber çok daha yüksek yerdeğiştirme değerlerine ulaşabilmiştir. $\mathrm{Bu}$ kirişin çatlak dağılımına bakıldığında çelik fiber katkılı kirişlerin aksine bu kirişte orta bölgede genişlikleri $2 \mathrm{~mm}$ ile $5 \mathrm{~mm}$ arasında değişen dört büyük çatlağın oluştuğu görülmektedir. Çelik fiber katkılı kirişlerde ortada oluşan ana çatlağın dışında oluşan çatlaklar çelik fiberlerden dolayı genişleyememekte, tüm deformasyon en büyük momentin geliştiği orta bölgedeki ilk çatlakta toplanmaktadır. Boyuna çekme donatısı bu çatlakta yerel olarak çok yüksek birim şekil değiştirmelere maruz kalmakta ve artan yük altında çatlağın genişlemesi sonucu çelik fiberlerin sıyrılmasıyla boşalan çekme yükünü taşıyamayarak kopmaktadır. Ancak çelik fibersiz kirişte oluşan tüm çatlaklar genişleyebilmekte, bunun sonucunda boyuna donatı üzerindeki gerilme yoğunlaşmaları daha uzun bir bölgede oluşarak daha yüksek uzamalara izin vermekte ve kiriş çok daha yüksek yerdeğiştirme değerlerine ulaşabilmektedir.

K2s0 numunesi çelik fiber katk1sı içermeyip beklenildiği gibi çok ani bir şekilde gelişen eğik çekme çatlağ neticesinde göçmüştür (Şekil 5.a). Göçme yükü 72,8 kN olup hesaplanan yükten yaklaşı \% $\%$ daha yüksektir. Bu serideki diğer kirişler ise yüksek yerdeğiştirme kapasitesi göstermiş, kirişler göçmeye uğramadan deney düzeneğinin deformasyon kapasitesine ulaşıldığı için deneyler durdurulmak zorunda kalınmıştır. Çelik fiber katkılı kirişler K2s0'a göre yaklaşık \%38 daha yüksek yük kapasitesine ulaşmışlardır. Çelik fiberlerin davranışa en önemli katkısı 


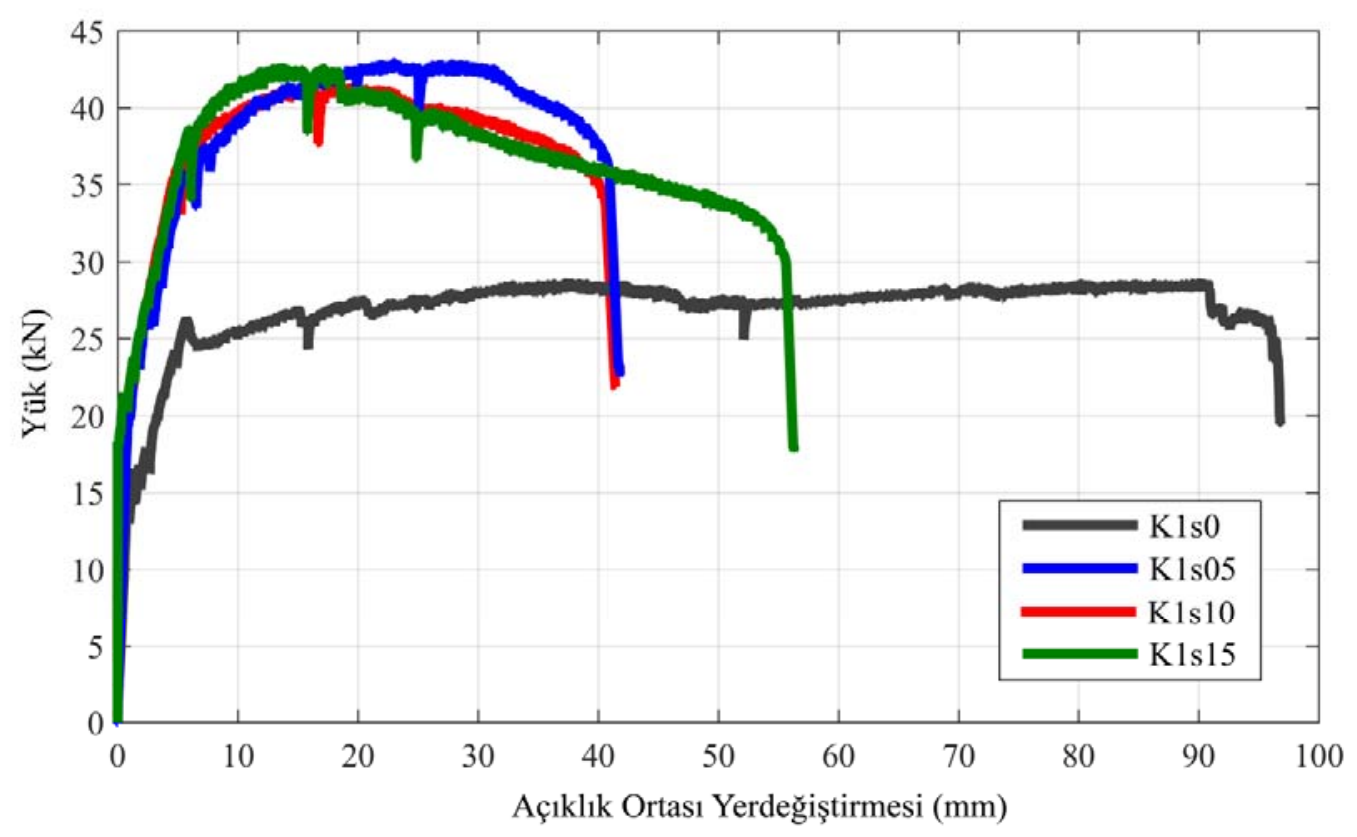

(a) K1 serisi

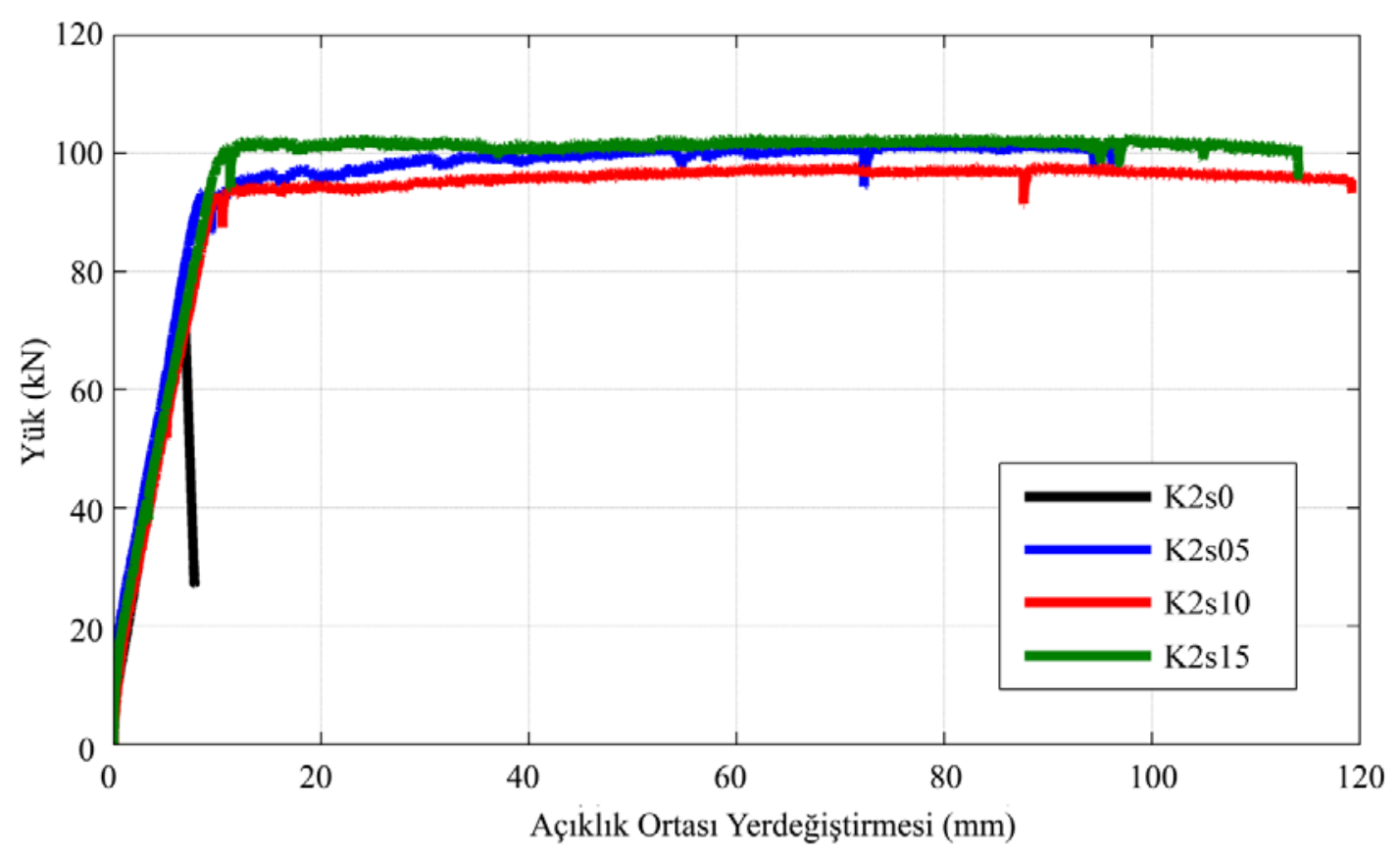

(b) K2 serisi

Şekil 3. Kirişlerin yük-yerdeğiştirme eğrileri (Load-displacement curves for beams)

gevrek kesme göçmesini sünek eğilme göçmesine çevirmeleri olmuştur. Çelik fiberler kirişlerde ilk oluşan eğik kesme çatlaklarının açılmasını engellemiş, etriye görevi görerek boyuna donatının akmasına imkân verecek şekilde kirişin yük kapasitesini arttırmışlardır. Ancak K1 serisi kirişlerde gözlemlenen duruma benzer olarak K2 serisi kirişlerde de çelik fiber katkısı oranının arttırılması dikkate değer bir yük kapasitesi artışına yol açmamıştır. Artan fiber oranının yerdeğiştirmelere olan etkisi ise kirişlerdeki yüksek deformasyonun test düzeneğinin sınırlarına dayanması sebebiyle deneylerin göçme olmadan durdurulmak zorunda kalınması neticesinde gözlemlenememiştir. Öte yandan çelik fiber oranının çatlak dağılımına etkisi gözlemlenebilmiştir. Çelik fiber oranı arttırıldıkça çatlak sayısı azalmış, çatlak genişlikleri artmıştır. Başka bir deyişle düşük çelik fiber oranı olan K2s05 numunesinde orta bölgede çok sayıda dar çatlaklar oluşurken yüksek çelik fiber oranına sahip K2s15 numunesinde daha az sayıda ancak daha geniş çatlaklar 


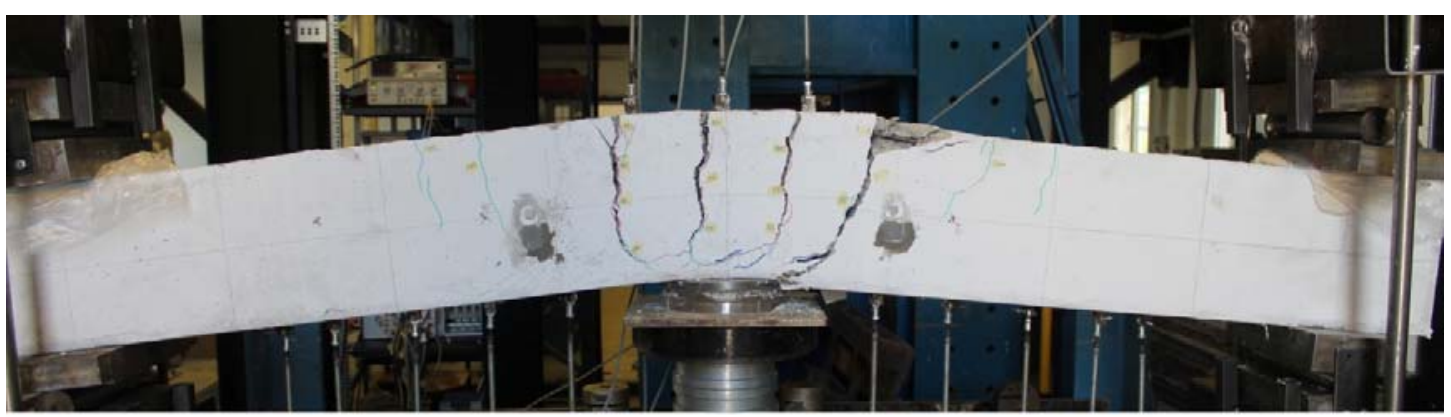

(a) $\mathrm{K} 1 \mathrm{~s} 0$

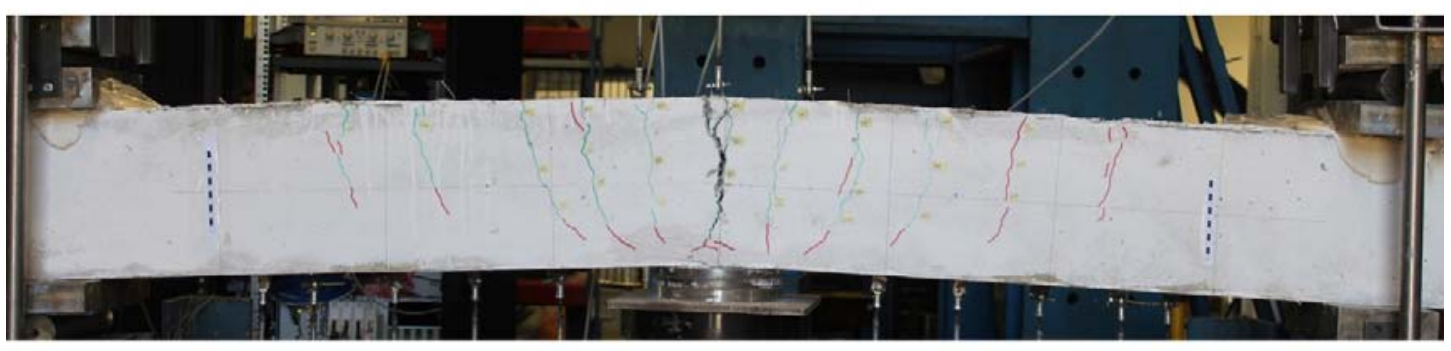

(b) K1s05

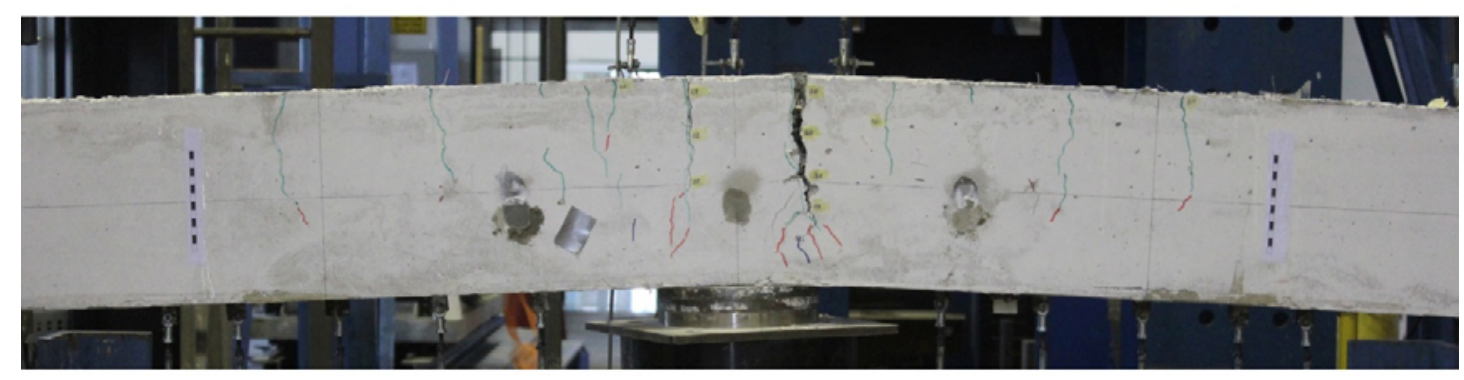

(c) K1s10

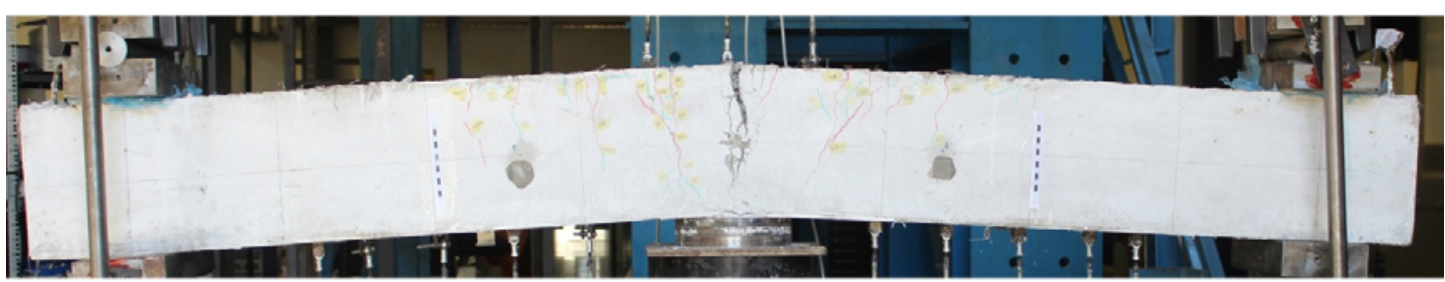

(d) K1s15

Şekil 4. K1 serisi kirişlerin göçme sonrası görünüşleri (After failure views of K1 series beams)

oluşmuştur. K1 serisinde gözlemlendiği gibi burada da yüksek çelik fiber oranının oluşan çatlakların daha fazla genişlemesine izin vermeyerek tüm deformasyonun az sayıda çatlakta toplanmasına sebep olduğu sonucu çıkarılabilir.

Çelik fiber katkısının temel işlevi çatlayan betonda çatlak yüzeyleri arası bir köprü oluşturarak betonun çatlama sonrası da çekme yükü taşımasına olanak sağlamasıdır [9]. Çatlama sonrası çelik fiberlerin çatlak yüzeyleri arasında iletebildikleri çekme gerilmesinin çatlak genişliğine bağlı değişiminin modellenmesi üzerine literatürde çok sayıda çalışma mevcut olup bu modeller genellikle doğrudan çekme deneyleri üzerinde geliştirilen modellerdir [10]. $\mathrm{Bu}$ modellerin çelik fiber katkılı kirişlerin eğilme davranışının belirlenmesi amacıyla kullanımında iki farklı yaklaşım takip edilmektedir. Birinci yaklaşımda çatlak genişliği veya kirişin anlık eğriliğinden bağımsız olarak kesitin çatlamış bölümünde sabit ortalama bir çekme gerilmesi kabul edilmekte ve eğilme kapasitesi hesapları bu gerilmeye göre yapılmaktadır [7]. İkinci ve daha karmaşık yaklaşımda ise çatlamış kesimdeki gerilmeler çatlak genişliği ile ilişkilendirilmekte ve dolayısıyla kirişin geometrik özellikleri, çelik donatı miktarı ile yükleme ve mesnet 


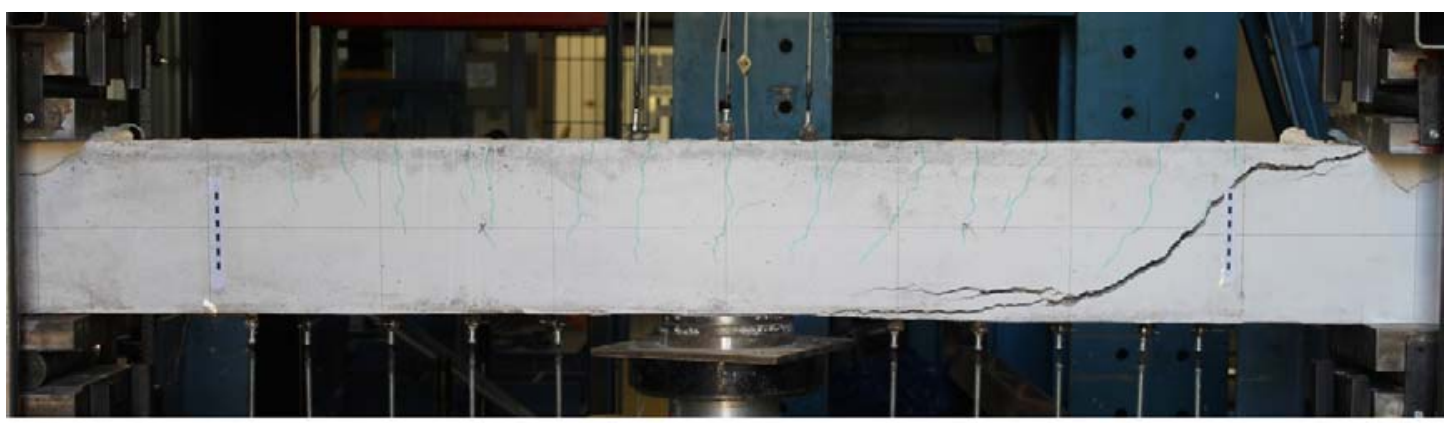

(a) $\mathrm{K} 2 \mathrm{~s} 0$

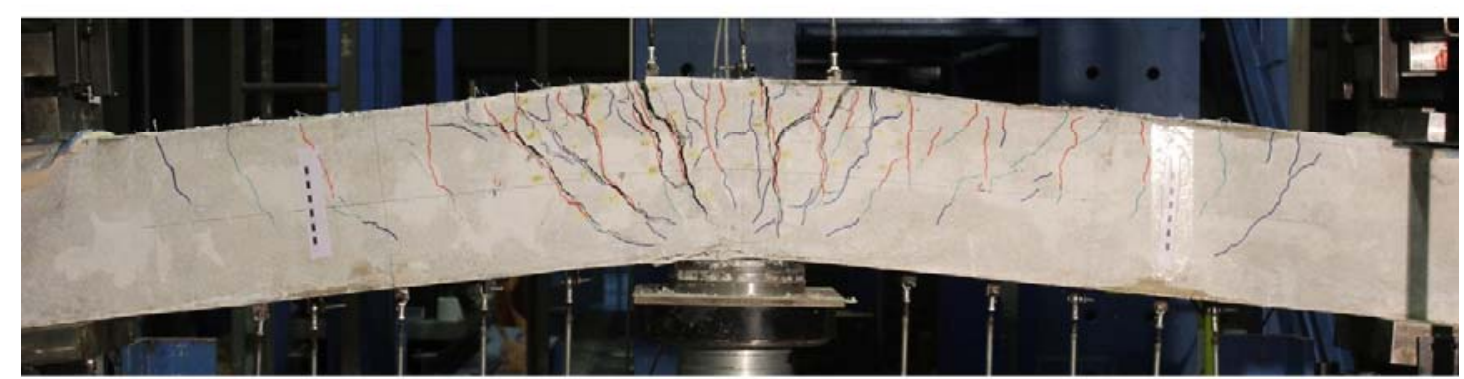

(b) K2s05

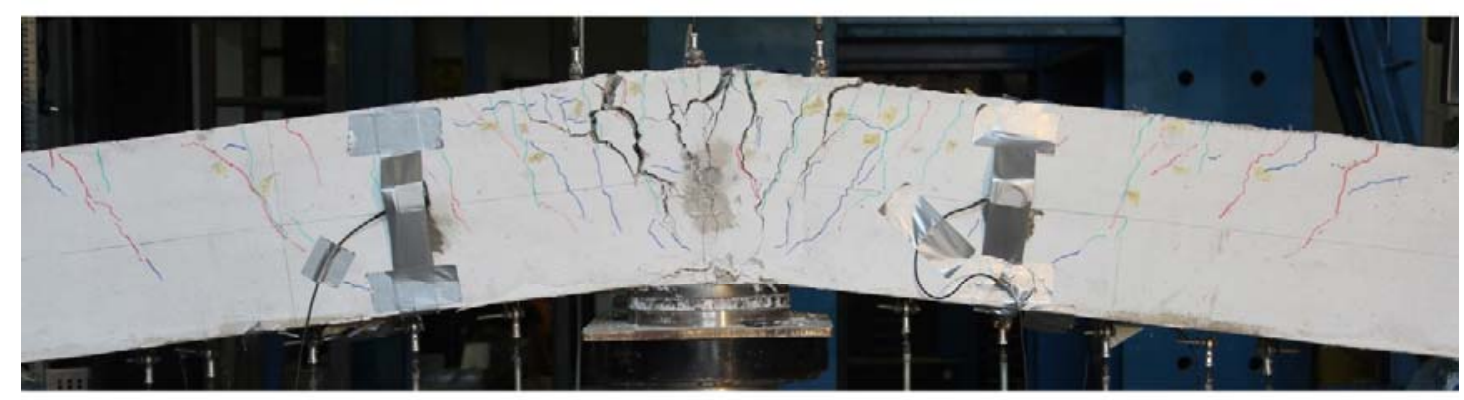

(c) $\mathrm{K} 2 \mathrm{~s} 10$

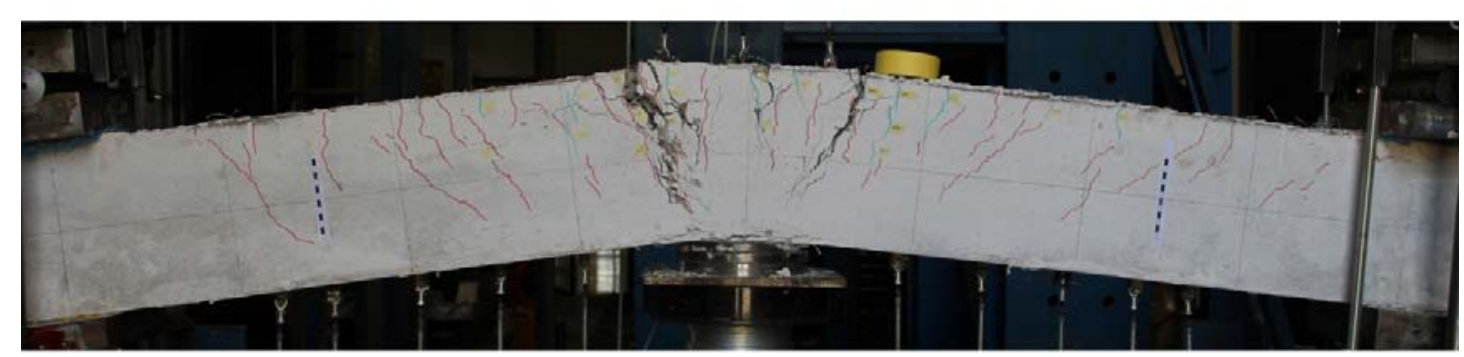

(d) K2s15

Şekil 5. K2 serisi kirişlerin göçme sonrası görünüşleri (After failure views of K2 series beams)

koşullarına bağlı olarak değişkenlik göstermektedir [11]. İlk bahsedilen yaklaşım genelde güvenli tarafta kalacak şekilde basit ve hızlı bir kesit eğilme kapasitesi hesabına imkan vermekte, ikinci yaklaşım ise çekme gerilmelerinin dağılımının daha doğru tahminine olanak verdiği için çatlak genişliklerinin tahmin edilebildiği koşullarda gerçeğe daha yakın sonuçlar vermektedir. Ancak eğilme yükü altındaki kirişlerde çatlak genişliklerinin yüksek doğrulukla tahmini ancak kirişte çatlağın tek bir noktada oluşmasının sağlandığ1 (örneğin maksimum momentin olduğu kesitte çekme bölgesinde çentik birakarak) durumlarda mümkün olduğundan ve daha genel yük ve sınır koşulları altında çatlak sayısı ve genişliğinin tahmini kaba varsayımlara dayandığından ikinci yöntemin uygulanabilirliği daha kısıtlıdır. Bu çalışmada uygulanabilirliği daha yüksek olduğu için deney kirişlerinin analizi için ilk yaklaşım tercih 
edilmiştir. Bu yaklaşıma ait çatlamamış ve çatlamış kesitte öngörülen tipik gerilme dağılımları Şekil 6 'da verilmiştir. Modelde düzlem kesitlerin deformasyon sonrası düzlem kaldığı varsayılmıştır. Betonun çatlamaya kadar gerilmebirim şekil değiştirme ilişkisi doğrusal kabul edilmiş, Naaman [12] tarafından tavsiye edildiği gibi çelik fiber katkılı betonun eğilmede çatlama dayanımı $f_{c r}$ normal betonla aynı kabul edilerek $\mathrm{f}_{\mathrm{cr}}=0.7 \sqrt{\mathrm{f}_{\mathrm{c}}^{\prime}}(\mathrm{MPa})$ olarak hesaplanmıştır.

Betonun elastisite modülü $E_{c}$ çelik fiber katkısından etkilenmediği varsayımıyla $E_{c}=4700 \sqrt{f_{c}^{\prime}}(\mathrm{MPa})$ olarak hesaplanmış, betonun birim çatlama şekil değiştirmesi $\varepsilon_{c r}$ ise $\varepsilon_{c r}=f_{c r} / E_{c}$ bağıntısıyla bulunmuştur [3]. Bu denklemlerde $f_{c}^{\prime}$ çelik fiber katkısız normal betonun basma dayanımı olup hesaplarda Tablo 2'de belirtildiği gibi 42,4 MPa alınmıştır. Çelik fiber katkılı betonun basmada birim şekil değiştirmegerilme ilişkisi basitleştirilmiş bir varsayımla normal betonda olduğu gibi parabolik kabul edilmiş ve Hognestad modeli [13] kullanılmıştır. Bu modelde normal betondan farklı olarak çelik fiber katkılı betonun çok yüksek birim şekil değiştirmelere ulaşabildiği göz önüne alınıp tepe noktasından sonraki doğrusal kısım 0,010 birim şekil değiştirmesine kadar uzatılmıştır [14] (Eş. 1-Eş. 3).

$$
\mathrm{f}_{\mathrm{c}}=\mathrm{f}_{\mathrm{cc}}\left[2 \frac{\varepsilon_{\mathrm{c}}}{\varepsilon_{0}}-\left(\frac{\varepsilon_{\mathrm{c}}}{\varepsilon_{0}}\right)^{2}\right]
$$

$\varepsilon_{0} \geq \varepsilon_{\mathrm{c}}>0$ için

$\mathrm{f}_{\mathrm{c}}=\mathrm{f}_{\mathrm{cc}}\left[1-\frac{0,15}{0,004-\varepsilon_{0}}\left(\varepsilon_{\mathrm{c}}-\varepsilon_{0}\right)\right]$

$0,010 \geq \varepsilon_{\mathrm{c}}>\varepsilon_{0}$ için

$\mathrm{f}_{\mathrm{c}}=0$

$\varepsilon_{\mathrm{c}}>0,010$ için

$\mathrm{Bu}$ denklemlerde çelik fiber katkılı betonun maksimum basma gerilmesi $f_{c c}$ için Tablo 2'de verilen deney günlerinde tespit edilen basma dayanımları kullanılmış, bu gerilmeye denk gelen birim şekil değiştirme ise $\varepsilon_{0}=2 f_{c c} / E_{c}$ olarak hesaplanmıştır. Çatlamış betondaki çekme gerilmesi $f_{r}$ sabit kabul edilmiş, değeri ise Naaman'ın [12] çalışmasına dayanarak aşağıdaki gibi hesaplanmıştır.

$\mathrm{f}_{\mathrm{r}}=\lambda_{1} \lambda_{2} \lambda_{3} \tau \mathrm{V}_{\mathrm{f}}(\mathrm{L} / \mathrm{d})$

$\mathrm{Bu}$ denklemde $\lambda_{1}$ tahmini siyrılma uzunluğu oranını, $\lambda_{2}$ fiberlerin çatlaktaki konumuna göre etkinliğini, $\lambda_{3}$ fiberlerin yoğunluktan dolayı azalan etkinliklerini hesaba katan katsayılardır. $\lambda_{1}=0,25, \lambda_{2}=1,2, \lambda_{3}=1,0$, Naaman [12] tarafindan ucu kancalı çelik fiberler için önerilen değerlerdir. $V_{f}$ çelik fiber katkısı hacimsel oranını, $L / d$ ise fiber uzunluğunun fiber çapına oranını vermektedir. Denklemdeki $\tau$ çelik fiber ile beton arasındaki sıyrılma gerilmesi olup Valle ve Büyüköztürk [15] tarafindan $\tau=0,66 \sqrt{f_{c}^{\prime}}(\mathrm{MPa})$ olarak hesaplanması önerilmiştir. Çelik için gerilme-birim şekil değiştirme ilişkisi, pekleşme de göz önüne alınarak, üç parçalı doğrusal eğri olarak varsayılmıştır. Kirişlerin kesit analizleri, kesitin katmanlara bölünerek betonda varsayılan bir maksimum basma birim şekil değiştirmesine $\left(\varepsilon_{\mathrm{cc}}\right)$ denk gelen moment ve eğriliğin kuvvetlerin dengesinden hesaplanması ve bu varsayılan $\varepsilon_{\mathrm{cc}}$ değerinin $-0,010$ 'a kadar geniş bir aralıkta değiştirilerek moment-eğrilik ilişkisinin tamamının elde edilmesi suretiyle yapılmıştır [16]. Elde edilen moment-eğrilik davranışı Şekil 7'de verilmektedir. K2s0 kirişi kesme etkisiyle göçtüğünden bu kirişin momenteğrilik ilişkisi hesaplanmamıştır. Hesaplanan momenteğrilik ilişkileri kirişlerin yük-yerdeğiştirme eğrilerinin hesabında kullanılmıştır. Kirişin yarısı 20 eşit parçaya bölünmüş, belli bir yük altında her parçanın başı ve sonundaki noktalardaki moment ve bu momente denk gelen eğrilikler hesaplanan moment-eğrilik ilişkisinden bulunmuştur. Kirişin yarısı boyunca elde edilen eğrilik dağılımı kullanılarak bu yüke denk gelen açıklık ortası yerdeğiştirmesi moment-alan teorisi kullanılarak hesaplanmıştır. Yük değeri sıfırdan itibaren adım adım arttırılarak her bir kirişin yük-yerdeğiştirme eğrisi elde edilmiştir (Şekil 8). Bu yöntemde kiriş üzerinde belli bir yük altında moment dağılımı elde edilirken mesnetlerde ve yükün uygulandığı plakada yüklerin düzgün yayılı olduğu varsayılmış, kirişin kendi ağırlığı da hesaba katılmıştır. Kullanılan bu yöntemde yerdeğiştirme hesabı ancak kirişteki maksimum momentin hesaplanan moment-eğrilik

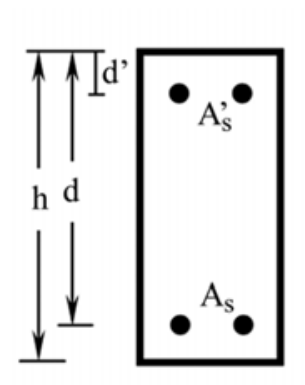

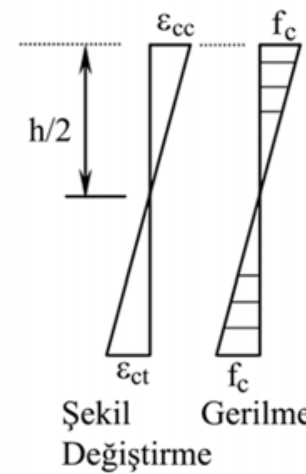

Çatlamamış kesit

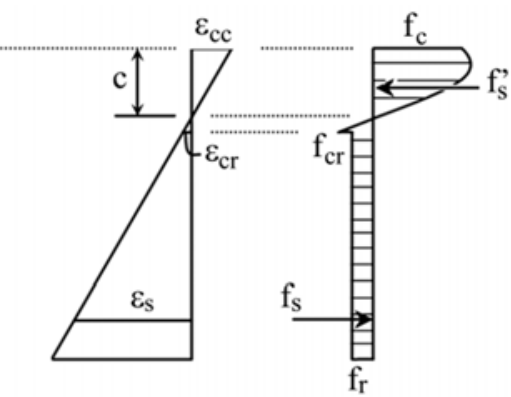

Şekil

Değiştirme
Gerilme

Çatlamış kesit

Şekil 6. Kesitte birim şekil değiştirme ve gerilme dağılımları (Strain and stress distribution on the cross-section) 


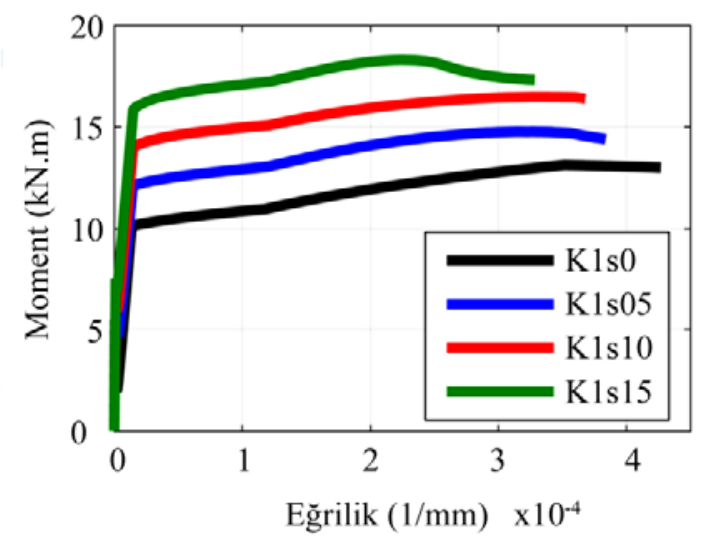

(a) K1 serisi

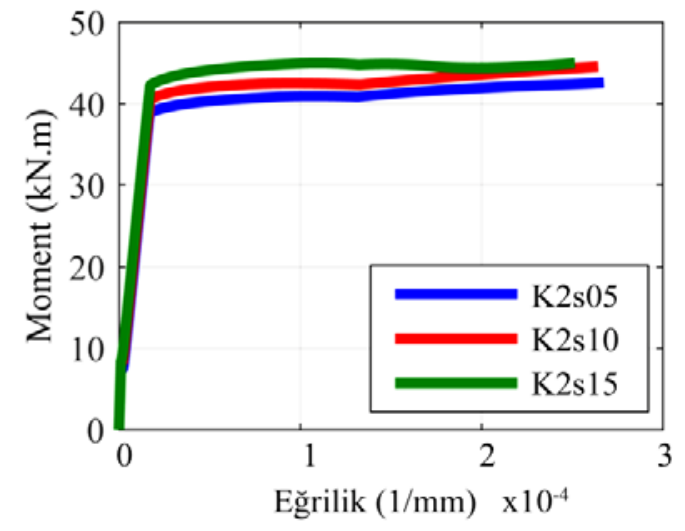

(b) K2 serisi

Şekil 7. Hesaplanan moment-eğrilik davranışı (Calculated moment-curvature response)

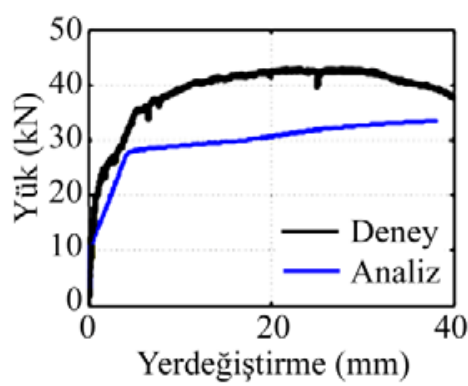

(a) $\mathrm{K} 1 \mathrm{~s} 05$

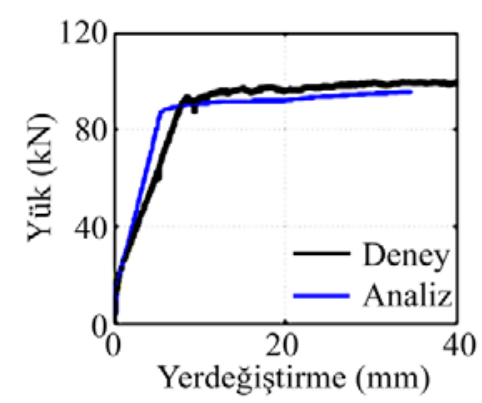

(d) $\mathrm{K} 2 \mathrm{~s} 05$

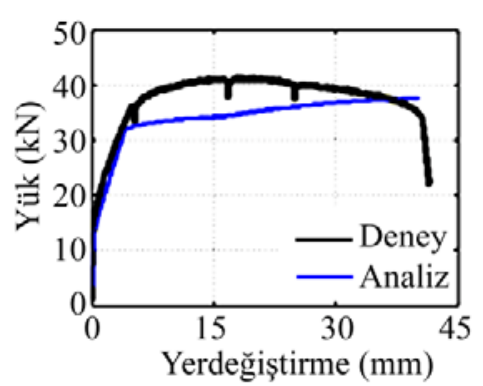

(b) K1s10

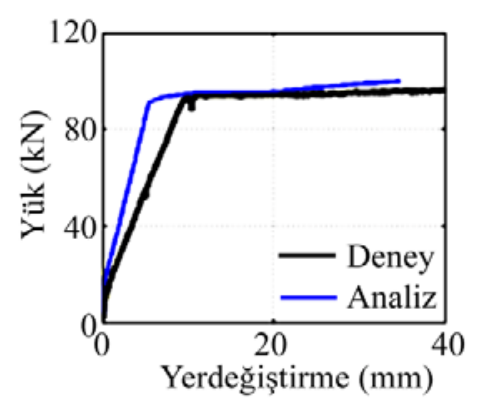

(e) $\mathrm{K} 2 \mathrm{~s} 10$

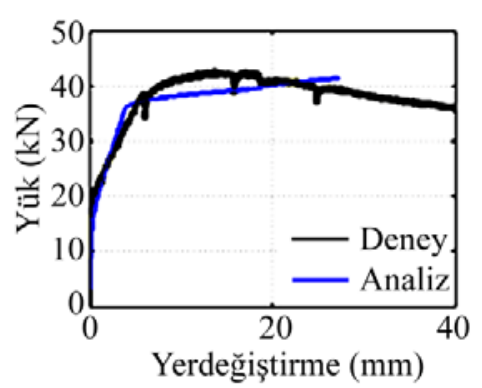

(c) $\mathrm{K} 1 \mathrm{~s} 15$

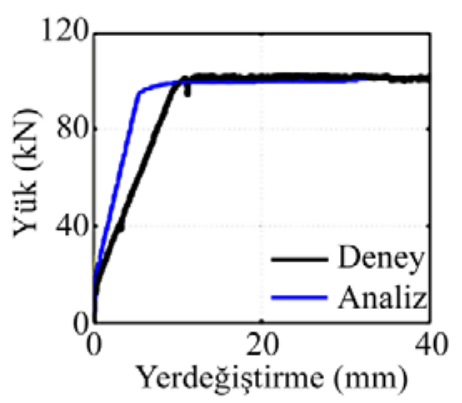

(f) K2s15

Şekil 8. Hesaplanan yük-açıklık ortası yerdeğiştirmesi davranışı (Calculated load-midspan displacement response)

ilişkisindeki maksimum momente denk geldiği yüke kadar yapılabilmiştir. Bir başka deyişle analiz artan yük üzerinden yapıldığından artan yerdeğiştirmelerde düşen yükü modellemek mümkün olmamıştır.

Şekil 8'den görüldüğü gibi K1 serisi kirişlerde boyuna donat1 akması öncesi eğilme rijitliği daha yakın hesaplanmışken K2 serisi kirişlerde hesaplanan eğilme rijitliği deneylerde gözlemlenenden daha yüksektir. Buna sebep olarak kirişlerin çatlak dağılımları gösterilebilir. Çelik fiber katkılı K1 serisi kirişlerde tek bir ana çatlak oluşmuş olup diğer çatlaklar çok daha dardır. K2 serisi kirişlerde ise çok daha fazla geniş çatlak oluşmuştur. Hesaplarda izlenilen yöntem çatlak sayısını ve çatlak aralıklarını hesaba katmadığından ve moment dağılımına göre en büyük eğriliğin her zaman ortadaki ana çatlakta olduğu varsayıldığından tek çatlak oluşması durumunda rijitlik açısından daha doğru sonuç alınmaktadır. Ancak çok sayıda geniş çatlak oluşumunda kiriş yapılan varsayımlara aykırı olarak daha yumuşak davranmakta ve hesabın yapıldığı belli bir yüke denk gelen yerdeğiştirmeler gerçektekinden daha düşük çıkmaktadır. Tablo 3'te kirişlerin deney ve analizden elde edilen maksimum yük ve maksimum yerdeğiştirme değerleri ve maksimum yükte deney ve analiz arasındaki hata oranı verilmiştir. Bazı deneyler göçme olmadan durdurulduğundan ve analizlerde maksimum yerdeğiştirme tam olarak elde edilemediğinden yerdeğiştirmeler için hata oranı hesaplanmamıştır. Tablo 3 'ten de görüldüğü gibi genel olarak maksimum yük için hesaplanan analiz sonuçları deney sonuçlarından düşüktür. K1 serisi kirişlerde hata oranı 
K2 serisine göre çok daha fazladır. Hesaplanan momenteğrilik ilişkileri incelendiğinde K1 serisi kirişlerde çelik fiber katkısının K2 serisi kirişlere göre daha büyük rol oynadığg görülmektedir. Artan çelik fiber katkısı K1 serisi kirişlerde hesaplanan yük kapasitesini K2 serisi kirişlerle kıyaslandığında daha çok arttırmaktadır. $\mathrm{Bu}$ gözlemde boyuna donatı oranının etkisi öne çıkmaktadır. Düşük boyuna donatı oranına sahip K1 serisi kirişlerde çelik fiber katkısının sebep olduğu çekme gerilmeleri daha büyük rol oynamakta, dolayısıyla farklı çelik fiber oranları için hesaplanan çekme gerilmeleri ve bu gerilmelerin hesabındaki hassasiyet eğilme kapasitesi hesabını daha büyük oranlarda etkilemektedir. Yüksek boyuna donatı oranına sahip K2 serisi kirişlerde ise boyuna donatı davranış1 hakim olmakta, çelik fiber katkısının getirdiği çekme kuvvetleri boyuna donatıda oluşan çekme kuvvetleri yanında çok daha küçük kalmaktadır. Sonuç olarak boyuna donatının davranışı daha iyi modellenebildiğinden çelik fiberden kaynaklanan çekme gerilmelerinin hesabındaki hata kesit davranışını fazla etkilememekte ve kesit eğilme kapasitesi ile yük-yerdeğiştirme eğrisi çok daha yüksek hassasiyetle hesaplanabilmektedir. Çatlamış kesitte çelik fiberlerin sebep olduğu çekme gerilmeleri analizlerde Eş. 4 kullanılarak hesaplanmıştır. Yaygın olarak kullanılan bu denklem basit ve kolay hesaplanır olmakla birlikte çekme gerilmelerini çatlak genişliğinden bağımsız ele almaktadır ve tüm çatlamış kesitte hesaplanan değeri sabit kabul etmektedir. Ancak yapılan çalışmalar çelik fiberlerin sebep olduğu çekme gerilmelerinin çatlak genişliği ile ilişkili olduğunu, çatlak genişliğinin artmasıyla çelik fiberlerin betondan sıyrılmaları neticesinde çatlak yüzeyleri arasında iletilen çekme gerilmelerinin azaldığını ortaya koymuştur [14]. Dolayısıyla bu çalışmadaki gibi bir eğilme durumunda çatlak boyunca çekme gerilmeleri değişken olacaktır. Çelik fiberlerin taşıdıkları çekme gerilmelerini çatlak genişliğine bağlı olarak veren modellere örnek olarak Basitleştirilmiş Kapsamlı Gömülme Modeli (Simplified Diverse Embedment Model, SDEM) örnek verilebilir [11]. Naaman'ın modeline [12] göre daha karmaşık olan bu model çok sayıda deneysel veri ile kıyaslanmış ve doğruluk derecesinin yüksek olduğu bildirilmiştir. Burada uzunluğundan dolayı ilgili formülasyona yer verilmemiştir. Ancak bu model kullanılarak bu çalışmadaki deney parametrelerine göre hesaplanan çatlak genişliğine karş1 çelik fiberlerin taşıdığı çekme gerilmesi ilişkisi Şekil 9'da verilmektedir. Tablo 4'te kullanılan çelik fiber katkısı oranları için Eş. 4'ten hesaplanan çekme gerilmesi değerleri ve SDEM formülasyonuna göre bu gerilmelere denk gelen çatlak genişlikleri verilmektedir. Deneyde ölçülen çatlak genişlikleri göz önüne alındığında Naaman [12] tarafından

Tablo 3. Deney ve analizlerde maksimum yük ve yerdeğiştirmeler (Maximum load and displacements in experiments and analyses)

\begin{tabular}{llllll}
\hline \multirow{2}{*}{ Numune } & Deney & \multicolumn{3}{c}{ Analiz } \\
\cline { 2 - 5 } & $\begin{array}{l}\text { Maksimum } \\
\text { Yük }(\mathrm{kN})\end{array}$ & $\begin{array}{l}\text { Maksimum } \\
\text { Yerdeğiştirme } \\
(\mathrm{mm})\end{array}$ & $\begin{array}{l}\text { Maksimum } \\
\text { Yük }(\mathrm{kN})\end{array}$ & $\begin{array}{l}\text { Maksimum } \\
\text { Yük Hata }(\%)\end{array}$ & $\begin{array}{l}\text { Maksimum } \\
\text { Yerdeğiştirme } \\
(\mathrm{mm})\end{array}$ \\
\hline K1s0 & 28,7 & 97 & - & & 38 \\
K1s05 & 42,9 & 42 & 33,4 & $-22,1$ & 40 \\
K1s10 & 41,5 & 41 & 37,4 & $-9,9$ & 27 \\
K1s15 & 42,6 & 56 & 41,4 & $-2,8$ & 35 \\
K2s0 & 72,8 & 8 & - & & 35 \\
K2s05 & 101,8 & 96 & 95,4 & $-6,3$ & 33 \\
K2s10 & 97,9 & 119 & 99,8 & 1,9 & $-2,1$ \\
K2s15 & 102,8 & 114 & 100,6 & -6 & \\
\hline
\end{tabular}

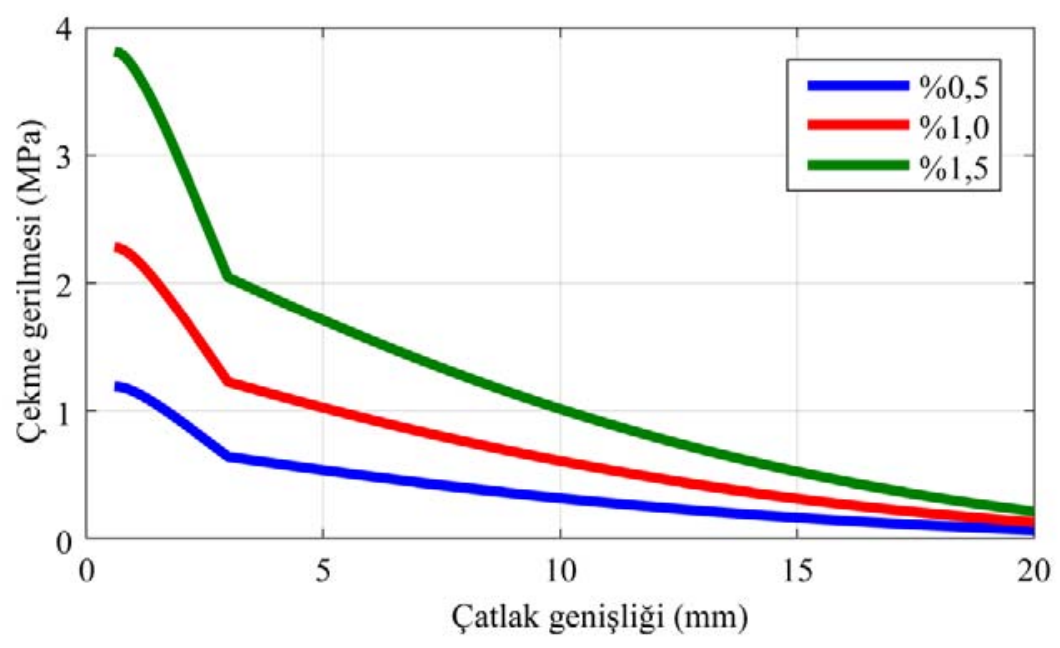

Şekil 9. SDEM'e göre çekme gerilmesi-çatlak genişliği ilişkisi (Tensile stress-crack width relationship according to SDEM) 
önerilen gerilme değerlerinin SDEM modeline göre göçme anına yakın yüksek deformasyonda görülen çatlak genişliklerine denk geldiği görülmektedir. $\mathrm{Bu}$ durum hesaplanan eğilme kapasitesinin deneyde gözlemlenenden daha düşük olması durumunu da açıklamaktadır. Eğilme altında çatlamış kesitte Eş. 4'te verilen çekme gerilmesi değerlerine ancak boyuna donatı aktıktan ve çatlak genişlikleri 4-5 mm mertebelerine ulaştıktan sonra düşmekte, daha öncesinde çatlakta çok daha yüksek çekme gerilmeleri taşınabilmektedir. Dolayısıyla bunu dikkate almayan Eş. 4'e göre hesaplanan eğilme kapasiteleri Şekil 8 'den de görüldüğü gibi güvenli tarafta olmakla birlikte gerçeğin altında hesaplanmaktadır.

Tablo 4. Çatlakta hesaplanan çekme gerilmeleri (Calculated tensile stresses at crack)

\begin{tabular}{lll}
\hline $\begin{array}{l}\text { Çelik fiber katk1 } \\
\text { oranı (\%) }\end{array}$ & $\begin{array}{l}\mathrm{f}_{\mathrm{r}}(\mathrm{Eş.} \text {. 4) } \\
(\mathrm{MPa})\end{array}$ & $\begin{array}{l}\text { SDEM'e göre } \\
\text { denk çatlak } \\
\text { genişliği }(\mathrm{mm})\end{array}$ \\
\hline 0,5 & 0,52 & 5,2 \\
1,0 & 1,03 & 4,9 \\
1,5 & 1,54 & 6,1 \\
\hline
\end{tabular}

\section{SONUÇLAR (CONCLUSIONS)}

Yapılan çalışmada çelik fiber katkısının betonarme kirişlerin eğilme davranışını önemli ölçüde etkilediği görülmüştür. Betonda çatlama sonrası çekme gerilmelerinin taşınmasını sağlayan çelik fiberler tüm kirişlerde eğilme kapasitesini önemli ölçüde arttırmış, çelik fiber katkısı olmadığı durumda gevrek kesme göçmesine uğrayan yüksek boyuna donatı oranına sahip kirişler çelik fiber katkısı ile sünek eğilme göçmesi göstermişlerdir. Ancak çelik fiber katkısı düşük boyuna donatı oranına sahip kirişlerde eğilme kapasitesini arttırmış olmakla birlikte deformasyonların tek bir çatlakta yoğunlaşmasına sebep olduğu için sünekliği azaltmış, kirişin donatı kopması ile aniden göçmesine sebep olmuştur. Bu durum bu kirişlerde boyuna donatı oranının çok düşük olması ve yükün tekil olarak uygulanması sebebiyle maksimum momentin tek bir noktada yoğunlaşmasından kaynaklanmış olabilir ve donatı oranının daha yüksek olması veya düzgün yayılı yük uygulanması durumunda farklılık gösterebilir.

Dolayısıyla bu tür kirişlerde çelik fiber katkısının kullanımının yol açabileceği sakıncalı durumlar için daha fazla çalışma yapılması gerekmektedir. Tüm kirişlerde çelik fiber oranının arttırılması eğilme davranışlarında önemli bir farklılığa yol açmamış, \%0,5, \%1,0 ve \%1,5 oranlarında çelik fiber katkısı kullanılan kirişler birbirlerine çok yakın yük-yerdeğiştirme ilişkisi göstermişlerdir. Tek farklılık düşük boyuna donatı oranına sahip $\% 1,5$ oranında çelik katkısı olan kirişte görülmüş, bu kiriş diğer çelik fiber katkılı kirişlere göre daha fazla yerdeğiştirme yapabilmiştir. Buna sebep olarak yüksek oranda çelik fiber içeren bu numunede çelik fiberlerin daha yüksek çatlak genişliklerine kadar yük taşıyabilmeleri gösterilebilir. Ancak aynı oranda çelik fiber katkısı içeren yüksek boyuna donatı oranına sahip kirişlerde deney düzeneğinin deformasyon sınırlarına ulaşıldığından kirişlerin göçme yerdeğiştirmeleri görülememiş, dolayısıyla aynı durumun bu kirişler için de geçerli olup olmadığ 1 tespit edilememiştir. $\mathrm{Bu}$ sebeple çelik fiber katkı oranının \%1 üzerinde arttırılmasının yerdeğiştirme kapasitesine olası etkilerini araştırmak için daha fazla çalışmaya ihtiyaç vardır.

Elde edilen deneysel sonuçların literatürde yaygın kullanılan modellere göre yapılan analizlerinde çatlamış kesitte çelik fiberlerin taşıdığı çekme gerilmelerinin doğru hesabının özellikle düşük boyuna donatı oranına sahip kirişlerde daha önemli olduğu gözlemlenmiştir. Bu kirişlerde çatlamış kesitte çelik fiberlerin çekme gerilmelerini sabit kabul eden basit yaklaşımın güvenli tarafta olmakla birlikte gerçeğinden daha düşük kapasite verdiği, daha doğru hesap için çekme gerilmelerini çatlak genişliği ile ilişkilendiren modellere ihtiyaç olduğu anlaşılmıştır. Boyuna donatı oranının yüksek olduğu kirişlerde ise çelik fiber katkısı kesme kapasitesini arttırmak suretiyle kirișin davranıșını önemli ölçüde değiştirmiş, ancak boyuna donatı gerilmeleri davranışa hakim olduğundan çelik fiberlerdeki çekme gerilmelerinin hesabındaki hassasiyet kapasite hesabını fazla etkilememiştir. Çelik fiber katkısının yük taşıyıcı elemanlarda donatı takviyesi olarak kullanımı için farklı yük, donatı ve mesnet koşullarında deneysel ve analitik çalışmalar yapılması ve daha hassas ve pratik modeller geliştirilmesi gerekmektedir.

\section{SIMMELER (SYMBOLS)}

As cekme donatisi alan

$\mathrm{A}_{\mathrm{s}}^{\prime} \quad$ basınç donatısı alanı

$\mathrm{E}_{\mathrm{c}} \quad$ betonun elastisite modülü

$L / d \quad$ çelik fiber uzunluğunun fiber çapına oranı

$V_{c r} \quad$ betonun eğik çatlama dayanımı

$V_{f} \quad$ çelik fiber katkısı hacimsel oranı

a mesnet ve yük arasındaki mesafe

$\mathrm{b}_{\mathrm{w}} \quad$ kiriş genişliği

d faydalı yükseklik (çekme donatısının kirişin basınç altındaki yüzünden olan mesafesi)

d' basınç donatısının kirişin basınç altındaki yüzünden olan mesafesi

$\mathrm{h} \quad$ kiriş toplam yüksekliği

$f_{c} \quad$ betonda basma gerilmesi

$f_{c}{ }^{\prime} \quad$ çelik fiber katkısı olmayan betonun basma dayanımı

$f_{c c} \quad$ çelik fiber katkısı olan betonun basma dayanımı

$f_{c r} \quad$ betonun eğilmede çatlama dayanımı

$f_{r} \quad$ çatlamış betonda çelik fiberlerden kaynaklanan çekme gerilmesi

$f_{s} \quad$ çekme donatısı gerilmesi

$f_{s}^{\prime} \quad$ basınç donatısı gerilmesi

$f_{t} \quad$ betonda çekme gerilmesi

$\varepsilon_{\mathrm{c}} \quad$ betonun birim şekil değiştirmesi

$\varepsilon_{\mathrm{cc}} \quad$ eğilmede betonda görülen maksimum basma birim şekil değiştirmesi

$\varepsilon_{\mathrm{cr}} \quad$ betonun çatlama birim şekil değiştirmesi

$\varepsilon_{\mathrm{ct}} \quad$ eğilmede betonda görülen maksimum çekme birim şekil değiştirmesi

$\varepsilon_{\mathrm{s}} \quad$ çelik boyuna donatının birim şekil değiştirmesi 
$\varepsilon_{0} \quad$ betonda maksimum gerilmeye denk gelen birim şekil değiştirme

$\lambda_{1} \quad$ tahmini siyrılma uzunluğu oranını hesaba katan katsay1

$\lambda_{2} \quad$ çelik fiberlerin çatlaktaki konumuna göre etkinliğini hesaba katan katsayı

$\lambda_{3} \quad$ çelik fiberlerin yoğunluktan dolayı azalan etkinliklerini hesaba katan katsayı

$\tau \quad$ çelik fiber ile beton arasındaki sıyrılma gerilmesi

\section{TEŞEKKÜR (ACKNOWLEDGEMENT)}

$\mathrm{Bu}$ makalede sunulan çalışma Türkiye Bilimsel ve Teknolojik Araştırma Kurumu (TÜBİTAK) tarafindan 112M822 sayılı proje kapsamında desteklenmiştir.

\section{KAYNAKLAR (REFERENCES)}

1. Murathan A., Murathan A., Karadavut S., Useability of high density polypropylene textile waste in composite material production, Journal of the Faculty of Engineering and Architecture of Gazi University, 29 (1), 9-14, 2014.

2. American Concrete Institute, Fiber Reinforced Concrete in Practice, Special Publication SP-268, Farmington Hills, Michigan, A.B.D., 2010.

3. American Concrete Institute, Building Code Requirements for Structural Concrete (ACI 318-11), Farmington Hills, Michigan, A.B.D., 2011.

4. Soutsos M.N., Le T.T., Lampropoulos A.P., Flexural performance of fibre reinforced concrete made with steel and synthetic fibres, Constr. Build. Mater., 36, 704710, 2012.

5. Susetyo J., Gauvreau P., Vecchio F.J., Steel fiberreinforced concrete panels in shear: Analysis and modeling, ACI Struct. J., 110 (2), 285-295, 2013.
6. Hameed R., Sellier A., Turatsinze A., Duprat F., Flexural behaviour of reinforced fibrous concrete beams: Experiments and analytical modelling, Pak. J. Engg. \& Appl. Sc., 13, 19-28, 2013.

7. Campione G., Simplified flexural response of steel fiber-reinforced concrete beams, J. Mater. Civ. Eng., 20 (4), 283-293, 2008.

8. Türk Standartları Enstitüsü, TS 500 Betonarme Yapıların Tasarım ve Yapım Kuralları, Ankara, Türkiye, 2000.

9. Deluce J.R. ve Vecchio F.J., Cracking behavior of steel fiber-reinforced concrete members containing conventional reinforcement, ACI Struct. J., 110 (3), 481-490, 2013.

10. Michels J., Christen R., Waldmann D., Experimental and numerical investigation on postcracking behavior of steel fiber reinforced concrete, Eng. Fract. Mech., 98, 326-349, 2013.

11. Lee S.C., Cho J.Y., Vecchio F.J., Simplified diverse embedment model for steel fiber-reinforced concrete elements in tension, ACI Struct. J., 110 (4), 403-412, 2013.

12. Naaman A.E., Strain hardening and deflection hardening fiber reinforced cement composites, Fourth International Workshop on High Performance Fiber Reinforced Cement Composites (HPFRCC4), Ann Arbor-A.B.D., 95-113, 2003.

13. Ersoy U. ve Ozcebe G., Betonarme, Evrim Yayınevi, Istanbul, 2015.

14. American Concrete Institute, ACI 544.4R-88 Design Considerations for Steel Fiber Reinforced Concrete, Farmington Hills, Michigan, A.B.D., 1988.

15. Valle $M$. ve Buyukozturk O., Behaviour of fiber reinforced high-strength concrete under direct shear, ACI Struct. J., 90 (2), 122-133, 1993.

16. Collins, M.P. ve Mitchell, D., Prestressed Concrete, Response Publications, Toronto, Kanada, 1997. 